\title{
GAYA KEPEMIMPINAN KHARISMATIK KYAI DALAM PENGEMBANGAN PONDOK PESANTREN
}

\author{
Yaya Suryana \\ Universitas Islam Negeri Sunan Gunung Djati Bandung \\ yayasuryana@uinsgd.ac.id.

\section{Heri Khoiruddin} \\ Universitas Islam Negeri Sunan Gunung Djati Bandung \\ herikhoiruddin@uinsgd.ac.id.
}

\section{Thia Oktapiani}

Universitas Islam Negeri Sunan Gunung Djati Bandung thiaoktapiani58@gmail.com

\begin{abstract}
ABSTRAK
Kepemimpinan kyai di beberapa pondok pesantren mengalami perubahan, dari beberapa kasus, perkembangan dimulai dari perubahan gaya kepemimpinan, dari kharismatik ke rasionalistik, dari otoriter-paternalistik ke diplomatikpartisipatif atau dari laissez faire ke demokratif. Kepemimpinan seorang kyai di pondok pesantren bertumpu pada kharisma, perubahan penyesuaian yang terjadi di pondok pesantren menunjukkan bahwa kyai mampu menyesuaikan diri dengan perkembangan masyarakat khususnya sistem pendidikan nasional. Metode penelitian menggunakan pendekatan kualitatif dengan metode deskriptif, dengan teknik pengumpulan data yang digunakan meliputi wawancara, observasi partisipasi, dan studi dokumentasi. Pelaksanaan kepemimpinan kyai di pondok pesantren mengalami kesuksesan, ditandai dengan bertambah jumlah santri dalam setiap tahunnya, mengembangkan lembaga, baik lembaga formal maupun non formal, santri yang telah lulus dan pulang ke rumahnya masingmasing dipercaya oleh masyarakat untuk memimpin setiap kegiatan keagamaan.
\end{abstract}

Kata Kunci: kepemimpinan, kharismatik, kyai, pondok pesantren.

\begin{abstract}
Charismatic leadership has an extraordinary attractiveness or influence to influence others, so that it has very many followers. The role of the clerics as leaders of Islamic boarding schools will succed in carrying out their leadership if the is a charismatic person, so with authority and influence he has great authority in developing Islamic boarding schools. The research method uses a qualitative approach with descriptive methods, with data collection techniques used, including interviews, participant observation, and documentation studies. The implementation of the kyai leadership in Islamic Boarding schools experienced succes, marked by an increase in the number of santri in each year, developing
\end{abstract}


institutions, both formal and non-formal institutions, students who had graduated and returned to their homes trusted by the community to lead every religious avtivity.

Key Words: leadership, charismatic, kyai, islamic boarding school.

\section{PENDAHULUAN}

Kepemimpinan adalah terjemahan dari kata leadership yang berasal dari kata leader. Pemimpin adalah orang yang memimpin, sedangkan pimpinan merupakan jabatannya. Dalam pengertian lain, secara etimologi istilah kepemimpinan berasal dari kata dasar "pimpin" yang artinya bimbing atau tuntun. Dari "pimpin" lahirlah kata kerja "memimpin" yang artinya membimbing dan menuntun (Hidayat \& Machali, 2012).

Kepemimpinan dalam hal ini berada dalam tiga kategori. Pertama, kepemimpinan tersebut berada dalam relasi dengan orang lain. Kedua, kepemimpinan merupakan suatu proses, dalam arti bahwa untuk bisa memimpin, seorang pemimpin tidaklah cukup mengandalkan posisi otoritas formalnya, tetapi harus melakukan sesuatu. Ketiga, suatu kepemimpinan haruslah memiliki kemampuan untuk membujuk atau lebih tepatnya memengaruhi orang lain untuk bertindak. Dalam hal ini membujuk dapat dilakukan melalui berbagai cara, seperti menciptakan model (keteladanan), memberi penghargaan dan hukuman, serta mengkomunikasikan suatu visi (Soebahar, 2013, p. 60)

Kepemimpinan meliputi lima macam kegiatan, yaitu mengambil keputusan, mengadakan komunikasi efektif, memberi semangat inspirasi dan motivasi kepada bawahan, memilih orang-orang yang menjadi anggota kelompoknya, dan memperbaiki pengetahuan dan sikap-sikap bawahan agar mereka terampil dalam usaha mencapai tujuan yang telah diterapkan (Fauzi, 2016, pp. 215-216).

Terdapat beberapa tipe kepemimpinan, salah satunya adalah tipe pemimpin yang berkharisma. Kharisma berasal dari bahasa Yunani, berarti "karunia yang diinspirasi ilahi". Bentuk pengaruh yang dimiliki pemimpin bukan karena tradisi/kewenangan melainkan pemimpin memperoleh karunia Tuhan, berupa kemampuan luar biasa. Kharisma muncul bila terjadi krisis sosial, dimana pemimpin muncul dengan visi radikal yang dapat memberi solusi memuaskan. Kepemimpinan kharismatik lebih dari sekedar keyakinan terhadap kepercayaan, tetapi memiliki kemampuan supranatural. Bawahan sebagai bagian kepemimpinan kharismatik tidak hanya percaya dan hormat kepada pemimpin, tetapi menjadikan idola dan pujaan sebagai figur spiritual (Zunaih, 2017).

Sunardi (2017) mengemukakan terdapat beberapa ciri-ciri kepemimpinan kharismatik yaitu yang pertama adalah berpengetahuan, bahwa seorang pemimpin harus memiliki kemampuan dalam bidang yang dipimpinnya dan mengetahui seluk-beluk bidang kegiatannya, baik dari dalam maupun dari luar. Ciri kedua adalah mempunyai keberanian dan inisiatif. Keberanian merupakan kemampuan batin yang mengakui adanya rasa takut, akan tetapi mampu menghadapi bahaya atau rintangan dengan tenang dan tegas.

Ciri kepemimpinan kharismatik yang ketiga menurut Sunardi (2017) adalah tegas, bijaksana, adil dan taat. Tegas disini dapat diartikan mempunyai kesanggupan untuk mengambil keputusan-keputusan dengan segera bila 
dibutuhkan dan mengutarakannya dengan tegas, lengkap dan jelas. Ketegasan bersumber pada keyakinan dan kepercayaan kepada diri sendiri. Ciri keempat adalah mempunyai pembawaan yang baik, semangat yang besar dan memiliki keuletan. Pembawaan atau tampang dan sikap seseorang berarti penjelmaan yang nyata dari isi yang harus dimiliki oleh seorang pemimpin. Ciri kelima adalah tidak mementingkan diri sendiri dan dapat menguasai diri sendiri. Seorang pemimpin yang tidak akan mengambil keuntungan dari pekerjaan kelompok untuk kepentingan diri sendiri serta tidak menyalahgunakan jabatannya. Ciri keenam adalah bertanggungjawab, ikhlas dan bisa menjalin kerjasama yang baik. Dan ciri yang terakhir adalah dapat menguasai persoalan secara terperinci dan menaruh simpati serta pengertian.

Salah satu pemimpin yang biasanya memiliki tipe kharismatik adalah pemimpin pondok pesantren. Kata pesantren sering digunakan dalam bahasa sehari-hari dengan tambahan kata "pondok" menjadi "pondok pesantren". Ditinjau dari segi bahasa, kata pondok dengan kata pesantren tidak ada perbedaan yang mendasar diantara keduanya karena kata Hakikatnya pondok pesantren merupakan lembaga pedidikan Agama Islam (Engku \& Zubaidah, 2014, p. 172).

Menurut istilah pondok pesantren adalah lembaga pendidikan tradisional Islam untuk mempelajari, memahami, mendalami, menghayati dan mengamalkan ajaran Islam dengan menekankan pentingnya moral keagamaan sebagai pedoman perilaku sehari-hari (Zulhimma, 2013). Pondok pesantren dilihat berdasarkan keterbukaannya terhadap perubahan-perubahan sosial, digolongkan dalam tiga kategori, yaitu pertama pesantren salafi yang tetap mempertahankan pengajaran kitab-kitab Islam klasik sebagai inti pendidikan di pesantren. Sistem madrasah diterapkan untuk memudahkan sistem sorogan yang dipakai dalam lembaga-lembaga pengajian bentuk lama, tanpa mengenalkan pengajaran pengetahuan umum. Kedua adalah pesantren khalafi, yang telah memasukkan pelajaran-pelajaran umum dalam madrasah-madrasah yang dikembangkannya, atau membuka tipe sekolah-sekolah umum dalam lingkungan pesantren. Dan ketiga adalah pesantren campuran/kombinasi, menggabungkan dua sistem yang berbeda yaitu sistem salafi dan khalafi sekaligus sebagaimana penjelasan diatas (Komariah, 2016). Sebagian besar yang ada sekarang adalah pondok pesantren yang berada diantara rentangan dua pengertian diatas (Fithriah, 2018).

Zulhimma (2013) menyatakan terdapat lima elemen dalam suatu pondok pesantren, yaitu kyai, pondok, mesjid, santri, pengajaran kitab-kitab klasik. Kyai adalah tokoh sentral dalam satu pesantren, maju mundurnya pesantren ditentukkan oleh wibawa dan kharisma sang kyai. Kata kyai berasal dari bahasa Jawa, yang semula kata itu dipakai untuk tiga jenis gelar yang saling berbeda yaitu gelar kehormatan bagi barang-barang yang dianggap keramat; gelar kehormatan untuk orang-orang tua pada umumnya; dan gelar yang diberikan oleh masyarakat kepada seorang ahli agama Islam yang memiliki atau menjadi pimpinan pesantren dan mengajar kitab-kitab Islam klasik pada para santrinya (Djasadi et al., 2012).

Kyai merupakan figur sentral setiap pesantren, dimana kyai selain memiliki keilmuan yang tinggi tetapi juga merupakan pendiri, pemilik dan pewakaf pesantren. Kyai juga merupakan pemegang kedaulatan atau kepemimpinan di 
pondok pesantren, dengan ciri-ciri khas yang bersifat kharismatik dan independent (Ansor, 2014).

Kepemimpinan kyai di pondok pesantren sangat strategis. Hal ini karena kyai memiliki kewenangan penuh dalam mengatur pondok pesantren yang dipimpinnya. Mengenai kekuasaan seorang kyai yaitu memiliki kewenangan yang penuh tentang kelangsungan hidup dan keberadaan pondok pesantren. Kewenangan yang dimiliki oleh seorang kyai terkait dengan kebijakan diantaranya yaitu menentukan visi, misi, tujuan pesantren, program yang akan dijalankan di pondok pesantren. Sedangkan kewenangan seorang kyai terkait operasional meliputi berbagai hal diantaranya manajemen pembelajaran, manajemen kurikulum, manajemen sarana dan prasarana, manajemen sumber daya manusia, manajemen pembiayaan dan lain-lain (Djasadi et al., 2012).

Kedudukan seorang kyai di pondok pesantren yaitu bagaikan jantung untuk kehidupan umat manusia, sebab kyailah sebagai perintis, pendiri, pemimpin, pengasuh, pengelola bahkan sebagai pemilik tunggal pondok pesantren. Untuk menjadi seorang kyai dan juga diakui ke-kyai-annya yaitu dengan kedalaman ilmu agama yang dimilikinya, kesungguhan dalam perjuangannya, keteladanan bagi umatnya, kekhusyuan dalam beribadah, dan kewicaraan dalam memimpin (Faris, 2015).

Peran seorang kyai sebagai pemimpin pondok pesantren akan berhasil dalam kepemimpinannya pada saat ia memiliki pribadi yang berkharismatik. Kyai kharismatik biasanya mempunyai keunggulan dibandingkan dengan kyai lainnya, seperti memiliki mental spiritual, kesalehannya dan kecakapannya. Seorang pemimpin kharismatik yaitu seseorang yang sangat percaya diri, ia meyakini dalam dirinya bahwa memiliki kemampuan yang lebih dari orang lain dan memiliki ide-ide yang cemerlang (Djasadi et al., 2012).

Sebuah pondok pesantren mempunyai peran yang sangat penting utamanya dalam pendidikan. Dan dalam kiprahnya menyelenggarakan pendidikan keagamaan telah teruji sejak lama. Pondok pesantren merupakan sebuah lembaga yang sangat penting dalam menyebarkan Agama Islam. Dapat dikatakan demikian karena kegiatan di pondok pesantren merupakan kegiatan yang membina santrinya untuk menjadi tokoh agama (Kusdiana, 2014, p. 2).

Banyak sekali pondok pesantren di Kabupaten Purwakarta, salah satunya adalah Pondok Pesantren Al-Hikamusslafiyah yang mengikuti sistem salaf dalam lembaga pendidikannya. Sekalipun menggunakan sistem pendidikan salaf, pondok pesantren sejauh ini mampu dalam merespon segala perkembangan zaman yang terjadi. Ini ditandai dengan jumlah santri yang meningkat setiap tahunnya yang menempuh pendidikan di Pondok Pesantren Al-Hikamussalafiyah Purwakarta.

Kyai memiliki peran dalam membimbing masyarakat sekitarnya. Bagi pondok pesantren memiliki pengamalan di masyarakat merupakan sebuah keharusan, seringkali dibuat tolak ukur keberhasilan santri yang telah berjuang di masyarakat. Kyai memiliki peran di masyarakat masing-masing, dan sesuai dengan kebutuhan masing-masing. Kyai juga termasuk sosok yang berwibawa, unsur kharismatik kyai memegang peranan penting dalam menjalankan kepemimpinannya (Ibrahim, 2014).

Di Pondok Pesantren Al-Hikamussalafiyah Purwakarta, kedudukan kyai bukan hanya memberikan ilmunya kepada santri, tetapi juga berperan sebagai 
tokoh nonformal yang ucapan-ucapan serta perilakunya akan dicontoh oleh masyarakat sekitar. KH. Adang Badruddin, selain memimpin pondok pesantren, beliau juga berperan dalam pengembangan pendidikan di masyarakat. Beliau secara langsung mengadakan pengajian rutin yang dikhususkan untuk masyarakat sekitar yang diadakan di aula/majlis pondok pesantren untuk memberikan pemahaman kepada masyarakat tentang agama. Berdasarkan hasil studi pendahuluan ini, penulis tertarik untuk menggali lebih dalam bagaimana gaya kepemimpinan kharismatik $\mathrm{KH}$ Adang Badruddin selaku pimpinan Pondok Pesantren Al-Hikamussalafiyah Purwakarta dalam mengembangkan pondok pesantrennya.

\section{METODE PENELITIAN}

Langkah-langkah yang akan dilakukan dalam penelitian ini meliputi menentukan pendekatan dan metode penelitian, menentukan jenis dan sumber data penelitian, menentukan teknik pengumpulan data penelitian, menentukan tempat dan waktu penelitian, serta menentukan uji keabsahan data penelitian. Penelitian ini menggunakan metode deskriptif kualitatif, menurut Moleong (2011) penelitian yang bertujuan untuk memahami fenomena yang dialami oleh subjek penelitian misalnya perilaku, persepsi, motivasi, tindakan dan lain-lain, secara holistik dan dengan cara deskripsi dalam bentuk kata-kata dan bahasa, pada suatu konteks khusus yang alamiah dan dengan memanfaatkan berbagai metode alamiah. Penelitian ini bertujuan untuk memahami fenomena yang terjadi, mendeskripsikan proses gaya kepemimpinan kharismatik kyai dalam pengembangan pondok pesantren di Pondok Pesatren Al-Hikamussalafiyah Purwakarta.

\section{HASIL DAN PEMBAHASAN \\ Konsep Kepemimpinan Kharismatik Kyai dalam Pengembangan Pondok Pesantren di Pondok Pesantren Al-Hikamussalafiyah Purwakarta}

$\mathrm{KH}$. Adang Badruddin lahir pada tahun 1948. Semasa kecilnya beliau mengahabiskan waktu dengan mengaji dan berguru kepada $\mathrm{KH}$. ljudin yang merupakan pemimpin Pondok Pesantren Al-Hikamussalafiyah pada waktu itu. Di tahun 1971 beliau menikah dengan putrinya $\mathrm{KH}$. ljudin yang bernama $\mathrm{Hj}$. Euis Jubaedah Arkah yang dikaruniai 8 orang anak yaitu $\mathrm{KH}$. Muhammad Asep Jabbar, KH. Hasbillah Hadami, KH. Dudus Abdul Kudus, Hj. Nyimas Badriah, Muhammad Mahmud, Hj. Enung Nazibah, Eva Fauziah, Demarwah. Di tahun 1999 sampai sekarang beliau meneruskan kepemimpinan $\mathrm{KH}$. ljudin yaitu memimpin Pondok Pesantren Al-Hikamussalafiyah Purwakarta. Beliau merupakan generasi keenam dalam meneruskan kepemimpinannya di Pondok Pesantren Al-Hikamussalafiyah Purwakarta. Selain memimpin pondok pesantren, beliau juga aktif dalam organisasi masyarakat dan organisasi politik yaitu sebagai Ketua Dewan Syuro di Partai Kebangkitan Bangsa (PKB) Jawa Barat pada periode 2017-2022, Wakil Rois Pengurus Wilayah Nahdhatul Ulama (PWNU) Jawa Barat pada periode 2016-2021, Ketua Forum Silaturahmi Guru Ngaji (FSGN) Nusantara, beliau yang mendirikan forum tersebut dengan tujuan untuk membentengi masyarakat dari paham-paham yang tidak sesuai dengan ajaran ahlussunnah wal jama'ah, melalui forum tersebut beliau mengajak kepada para ustadz atau guru ngaji untuk bersama-sama membentengi masyarakat dari 
paham-paham yang yang tidak sesuai dengan ahlussunnah wal jama'ah yaitu dengan cara dibina para ustadz tersebut lalu diajarkan kembali kepada masyarakat. Sehubungan dengan hal tersebut beliau mampu memanfaatkan jejaring, yaitu beliau membangun jejaring dengan instansi pemerintahan hal tersebut dilakukan untuk perkembangan pondok pesantren.

$\mathrm{KH}$. Adang Badruddin merupakan figur kyai yang tegas dan pemberi teladan yang baik. Beliau tidak pernah membeda-bedakan kepada santrinya, jika ada santri yang melakukan kesalahan, beliau akan menergurnya. Berdasarkan hasil penelitian, ketika itu salah satu dari pengurus yang mendapatkan tugas dari beliau dan dia berleha-leha, lalu pengurus tersebut ditegur dan dinasehati. $\mathrm{KH}$. Adang Badruddin selalu menghimbau kepada seluruh santrinya untuk melaksanakan shalat berjamaah, karena tidak ada alasan untuk meninggalkan shalat berjamaah selama kita masih mampu untuk melaksanakannya. Dengan akhlak lah beliau memberikan teladan kepada santrinya. Dengan semangat yang tinggi dan pantang menyerah, ketika sakit selama enam bulan, beliau selalu optimis dan semangat untuk sembuh. Setelah sembuh beliau melakukan aktivitasnya kembali dengan penuh semangat. Keteladannya juga terlihat ketika membantu santrinya yang sedang mengerjakan proses bangunan, beliau tidak merasa malu dengan melakukan hal tersebut.

Kedudukan kyai merupakan tokoh sentral, dapat dikatakan pondok pesantren jika memiliki lima elemen yaitu kyai, santri, masjid, asrama dan pengajaran kitab. Tidak ada pondok pesantren yang langsung berdiri tanpa adanya seorang kyai, jadi keberadaan kyai merupakan kunci utama dalam mencapai keberhasilan pondok pesantren, faktor yang sangat penting yang harus dimiliki oleh seorang kyai yaitu kharisma. Dengan kewibaannya, ia mampu mempengaruhi pengikutnya sehingga memiliki jumlah pengikut yang banyak, bukan karena aturan melainkan karena faktor kepribadiaannya. Dalam kepemimpinannya memiliki pengaruh yang sangat kuat bagi pengikutnya, hal tersebut terlihat semua santri, pengurus dan masyarakat meneladaninya. $\mathrm{KH}$. Adang Badruddin merupakan kyai yang kharismatik, terbukti dalam kepemimpinannya beliau memiliki jumlah santri yang banyak, setiap tahunnya selalu bertambah, bukan hanya dari masyarakat sekitar, banyak masyarakat dari luar daerah yang datang untuk memasukan putra-putrinya di pondok pesantrennya. Beliau juga memiliki banyak jamaah pengajian ibu-ibu dan bapakbapak yang diselenggarakan oleh pondok pesantren setiap sebulan sekali, jamaah datang dari masyarakat sekitar maupun masyarakat luar.

Salah satu ciri pemimpin kharismatik yaitu memiliki visi yang menarik mengenai gambaran masa depan organisasinya (Marginingsih, 2017). $\mathrm{KH}$. Adang Badruddin dalam kepemimpinannya mempunyai visi yang jelas yaitu Pondok Pesantren Al-Hikamussalafiyah Purwakarta sebagai lembaga pendidikan yang beraqidah Ahlussunnah Wal Jama'ah yang mampu membentuk pribadi santri menjadi insan kamil dan syamil, dan mampu mencetak intelektual muslim yang kompeten dengan bekal IMTAQ dan IPTEK. Visi tersebut dituangkan dalam misinya yaitu membentuk pribadi santri yang makrifat kepada Allah SWT, membentuk pribadi santri yang berakhlakul karimah, membentuk pribadi santri yang berilmu dan beramal shaleh, membentuk pribadi santri yang kompeten dalam menelaah kitab kuning, membentuk pribadi santri yang kreatif dan mandiri. Berdasarkan pernyataan tersebut, bahwa $\mathrm{KH}$. Adang Badruddin 
merupakan pemimpin yang kharismatik. Seorang pemimpin kharismatik sangat menjunjung tinggi apa yang telah dibuat dalam visi dan misinya, kyai sangat berpegang teguh pada prinsip yang ada pada dirinya. Seorang kyai dapat dikatakan berkharisma ketika kepemimpinannya memiliki prinsip yang kuat untuk kemajuan pondok pesantrennya. Di Pondok Pesantren Al-Hikamussalafiyah Purwakarta kepemimpinan yang dipegang oleh K.H. Adang Badruddin memiliki hal tersebut. Beliau sangat menjunjung tinggi ilmu agama, menurutnya hal yang utama untuk kehidupan dunia dan akhirat. Beliau selalu menjunjung tinggi visi pondok pesantren dan selalu menanamkan karakter yang baik bagi santrinya.

Faktor terpenting yang harus dimiliki oleh seorang kyai kharismatik yaitu kapasitas keilmuannya yang mumpuni dan akhlaknya yang baik, dari kapasitas ilmu dan akhlaknya, maka timbulah kharisma. Selain itu kharisma juga timbul karena faktor keturunan, jadi, jika seseorang dari keturunan orang yang terpandang dan didukung dengan kapasitas keilmuan yang mumpuni dan memiliki akhlak yang baik, maka dapat dikatakan berkharisma. Tapi tidak harus dari keturunan yang terpandang pun jika ia mampu membangun citra diri yaitu dengan memiliki ilmu yang mumpuni dan akhlak yang baik maka dapat dikatakan kyai kharismatik. KH. Adang Badrudin merupakan pemimpin yang kharismatik, karena dengan kapasitas keilmuannya, beliau menguasai berbagai ilmu keislaman seperti tafsir, hadits, tasawuf, fiqih dan ilm-ilmu keislamannya lainnya.

\section{Pelaksanaan Kepemimpinan Kharismatik Kyai dalam Pengembangan Pondok Pesantren di Pondok Pesantren Al-Hikamussalafiyah Purwakarta}

Program utama menurut $\mathrm{KH}$. Adang Badruddin yaitu mendidik santri, begitu masuk ke pondok pesantren, santri diajarkan tentang keimanan (tauhid), karena tauhid yang harus didahulukan, lalu diajarakan ilmu-ilmu lain seperti fiqih, akhlak dan lain sebagainya. Para santri setiap harinya memiliki kegiatan yang penuh, santri harus bangun lebih awal sebelum waktu subuh, wajib melaksanakan shalat fardhu berjamaah yang langsung dipimpin oleh $\mathrm{KH}$. Adang Badruddin, kegiatan mengaji yang diatur jadwalnya mulai dari pagi, siang, sore sampai malam. Seluruh santri wajib mengikuti semua program dan mentaati peraturan yang ada di Pondok Pesantren Al-Hikamussalafiyah Purwakrta.

Di Pondok Pesantren Al-Hikamussalafiyah Purwakarta terdapat beberapa program yaitu program harian, program mingguan, program bulanan, dan program tahunan. Program harian yang wajib diikuti oleh seluruh santri Pondok Pesantren Al-Hikamussalafiyah Purwakarta meliputi jadwal shalat berjamaah bersama $\mathrm{KH}$. Adang Badrudin, pengajian di kelas masing-masing yaitu kelas ibtida I (kelas I), kelas ibtida II (kelas II), kelas mutawasith (kelas III), dan kelas 'ali (kelas IV keatas), kegiatan tersebut dilaksanakan di majlis setiap asrama.

Program mingguan dan bulanan merupakan suatu kegiatan yang diadakan oleh pesantren bukan hanya bagi santri saja, tetapi pesantren mengadakan kegiatan bagi masyarakat yaitu pengajian bulanan dan agenda pertemuan dengan orang tua santri. Program mingguan yaitu kegiatan seni baca Al-Quran, ngiyas/nashrif lughowi, kegiatan muhadhorohan santri, pembacaan ratib dan yasin, dan program bulanan yaitu pertemuan dengan orang tua santri dan pengajian bulanan ibu-ibu dan bapak-bapak. Gambaran mengenai program mingguan dan bulanan tersebut sebagai berikut.

Tabel 1. Program Mingguan dan Bulanan 
Pondok Pesantren Al-Hikamussalafiyah Purwakarta

\begin{tabular}{cll}
\hline No & \multicolumn{1}{c}{ Program } & \multicolumn{1}{c}{ Hari } \\
\hline 1 & Seni baca Al-Qur'an & Malam Rabu \\
\hline 2 & Ngiyas/nashrif lughowi & Rabu sore \\
\hline 3 & Muhadhorohan & Malam Kamis \\
\hline 4 & Pengajian yasin dan ratib & Malam Jum'at \\
\hline 5 & Pertemuan orangtua/wali santri & Minggu pertama tiap bulan \\
\hline 6 & Pengajian Syahriyah & Minggu pertama tiap bulan \\
\hline
\end{tabular}

(Suryana, Khoiruddin, dan Oktapiani, 2019)

Program tahunan merupakan program yang diadakan setiap setahun sekali yang wajib diikuti oleh seluruh santri yaitu Haul Mama Izzudin, peringatan hari besar Islam yaitu Maulid Nabi Muhammad SAW, Isra' wal Mi'raj, musabaqoh, pasaran kitab dan pawai obor. Gambaran mengenai program tahunan tersebut sebagai berikut.

Tabel 2. Program Tahunan

Pondok Pesantren Al-Hikamussalafiyah Purwakarta

\begin{tabular}{cll}
\hline No & \multicolumn{1}{c}{ Program } & \multicolumn{1}{c}{ Waktu } \\
\hline 1 & Haul Mama 'Izzudin & 29 Muharam \\
\hline 2 & Maulid Nabi Muhammad SAW & Kamus akhir Rabi'ul Awal \\
\hline 3 & Isra' Wal Mi'raj & Kamis akhir bulan Rojab \\
\hline 4 & Musabaqoh Tahunan & Muharaam/Rajab \\
\hline 5 & Pasaran kitab Fathul Mu'in & $15-25$ Sya'ban \\
\hline 6 & Pasaran Ramadhan & $1-20$ Ramadhan \\
\hline 7 & Pawai obor dan musabaqoh tadarus Al-Qur'an & $1-20$ Ramadhan \\
\hline 8 & Pasaran kitab fathul Qharib dan Tijan Darory & $5-15$ Syawal \\
\hline
\end{tabular}

(Suryana, Khoiruddin, dan Oktapiani, 2019)

Penggerakan/pelaksanaan merupakan upaya untuk menggerakan atau mengarahkan tenaga kerja serta mendayagunakan fasilitas yang ada, dimaksudkan untuk melakukan pekerjaan secara bersama-sama (Hidayat \& Machali, 2012). Penggerakan memperoleh posisi yang terpenting dalam rangka merealisasikan tujuan yang ada dalam sebuah organisasi, penggerakan mencakup didalamnya salah satunya yaitu kepemimpinan, dalam rangka untuk mempengaruhi orang lain dalam mencapai sebuah tujuan. Didalam kepemimpinan berfungsi untuk memberikan arahan dan komando serta mengambil sebuah keputusan.

Tipe kepemimpinan apapun akan menerapkan fungsi actuating, karena fungsi tersebut merupakan langkah untuk merealisasikan tujuan-tujuan yang ada dalam kepemimpinannya yang kemudian dituangkan dalam program. Di sebuah lembaga khususnya lembaga pendidikan tidak akan berhasil tanpa ada komponen didalamnya bagitupun dalam pondok pesantren tidak akan mencapai tujuan yang diharapkan tanpa adanya elemen-elemen pondok pesantren yaitu kyai, pondok, mesjid, santri dan pengajaran kitab-kitab klasik. Seorang kyai merupakan kunci keberhasilan bagi pondok pesantrennya. Dan untuk mencapai tujuan yang diharapkan, maka seorang pemimpin harus merealisasikannya melalui program-program yang diselenggarakan di lembaganya tersebut. 
Seorang pemimpin yang kharismatik memiliki visi dan misi yang jelas, visi dan misi tersebut terealisasikan dalam sebuah program. $\mathrm{KH}$. Adang Badruddin dalam kepemimpinannya mempunyai program-program yang jelas bagi pondok pesantrennya yang terdiri dari program harian, program mingguan, program bulanan dan program tahunan. Semua program tersebut wajib diikuti oleh seluruh santrinya, bukan hanya santri yang dilibatkan dalam program tersebut tetapi masyarakatpun ikut dalam program yang diselenggarakan pesantren yaitu pada program pengajian syahriyah/bulanan.

\section{Keberhasilan yang dicapai dalam Pelaksanaan Kepemimpinan Kharismatik Kyai dalam Pengembangan Pondok Pesantren di Pondok Pesantren Al- Hikamussalafiyah Purwakarta}

Hasil yang dicapai dalam kepemimpinan KH. Adang Badruddin yaitu jumlah santri bertambah setiap tahunnya, di tahun ajaran 2018/2019 jumlah santri 5000 yang terdiri dari 1500 santri putra dan 3500 santri putri, sedangkan di tahun sebelumnya santri berjumlah 4000. Santri yang mendaftar ke Pondok Pesantren Al-Hikamussalafiyah Purwakarta bukan hanya berasal dari daerah Purwakarta saja, tetapi ada yang dari luar daerah yaitu dari Karawang, Subang, Bekasi, Jakarta bahkan ada yang dari luar pulau jawa. Santri yang mondok di Pondok Pesantren Al-Hikamussalafiyah Purwakarta memiliki latar belakang yang berbeda-beda, yaitu dari keluarga petani, pedagang, pegawai swasta, pengusaha dan lain-lain. Setelah berada di lingkungan pondok semua santri diperlakukan sama tanpa ada yang dibeda-bedakan, semua santri harus mengikuti aturan pondok pesantren dan melaksanakan kewajiban santri. Beliau memiliki tujuan dalam kepemimpinannya bahwa beliau bukan ingin banyak santri melainkan ingin banyak yang mengaji di pondok pesantrennya, harus rajin dalam sahalat berjamaah, rajin mengaji dan menjaga pada ajaran ahlussunnah wal jama'ah.

$\mathrm{KH}$. Adang Badruddin telah berhasil mengembangkan lembaganya. Pada awalnya pemimpin sebelumnya hanya mendirikan Madrasah Tsanawiyah (MTs) dan Madrasah Aliyah (MA), akan tetapi saat ini telah berkembang pesat mulai dari pendidikan formal maupun pendidikan non formal. Lembaga formal terdiri dari Raudhatul Athfal (RA), Madrasah Ibtidaiyah (MI), Sekolah Menengah Pertama (SMP), Sekolah Menengah Atas (SMA), Sekolah Menengah Kejuruan (SMK), Kampus 2 Universitas Islam Nusantara (Uninus) yang masih menginduk ke Uninus Bandung. Sedangkan pendidikan non formalnya yaitu Madrasah Diniyah Takmiliyah Awaliyah (MDTA). Hasil lebih yang dirasakan oleh beliau yaitu dibarengi dengan keberhasilan santrinya, di Pondok Pesantren AlHikamussalafiyah Purwakarta santri-santri yang sudah lulus dan pulang ke rumahnya masing-masing, mereka dipercaya oleh masyarakat sekitar untuk memimpin kegiatan-kegiatan keagamaan seperti ceramah, tahlilan, menjadi khatib dan lain-lain. Bahkan ada yang mendirikan lembaga sendiri dan memimpinnya. Karena beliau sering memberikan pesan kepada para alumni, setelah pulang ke rumahnya masing-masing santri harus memanfaatkan ilmunya di masyarakat yaitu mengajar ngaji, jika belum bisa mengaji maka harus belajar kepada orang lain dengan begitu maka hidup akan berkah.

Pondok pesantren mempunyai kekhasan sendiri yang tidak dimiliki oleh lembaga lainnya sehingga mampu mengembangkan diri dan masyarakatnya 
(Hidayat \& Machali, 2012). Karena pondok pesantren dalam melaksanakan aktivitasnya yang penuh yaitu selama 24 jam, pondok pesantren secara umum sangat mengakar pada masyarakat, pondok pesantren dan masyarakat merupakan satu kesatuan sehingga sangat penting dalam keterikatannya, pondok pesantren juga sangat dipercaya oleh masyarakat, sehingga banyak masyarakat yang memasukan putra-putrinya ke pondok pesantren untuk menuntut ilmu, karena di pondok pesantren pembinaan yang dilakukannya yaitu lebih mengutamakan pada pendidikan agama.

$\mathrm{KH}$. Adang Badruddin merupakan penerus Pondok Pesantren AlHikamussalafiyah Purwakarta, walaupun sebagai penerus bukan sebagai pendiri, beliau memiliki loyalitas yang tinggi terhadap pondok pesantrennya, karena adanya sikap tersebut beliau sadar terhadap maju mundurnya sebuah pondok pesantren yaitu tergantung kyainya (pemimpin). Beliau memiliki loyalitas yang tinggi terhadap pondok pesantren walaupun beliau sendiri pernah berkata bahwa dirinya penuh dengan keterbatasan, dengan latar belakang pendidikan yang non formal saja, tapi berkat keinginannya yang kuat dan tanggung jawabnya terhadap pesantren juga dibarengi dengan keikhlasan beliau mampu mengembangkan pondok pesantren sampai saat ini.

Dalam mencapai keberhasilan sebuah pondok pesantren tak lepas dari peran seorang kyai, dalam pengembangan kelembagaan pesantren kyai menjadi faktor utama, mulai dari pendirian sampai pengelolaannya. $\mathrm{KH}$. Adang Badrudin dalam kepemimpinannya melakukan pengembangan bagi lembaganya ditandai dengan adanya perubahan sistem di Pondok Pesantren Al-Hikamussalafiyah Purwakarta yang meliputi sistem kelembagaan, pendidikan dan bangunan. Lembaga yang didirikan meliputi lembaga formal dan non formal. Bukan hanya itu, perkembangan jumlah santri setiap tahunnya selalu bertambah.

\section{Faktor Pendukung dan Penghambat Pelaksanaan Kepemimpinan Kharismatik Kyai dalam Pengembangan Pondok Pesantren di Pondok Pesantren Al-Hikamussalafiyah Purwakarta}

Terdapat tiga faktor pendukung yaitu santri, alumni dan orang tua santri. Sebagian besar santri mengikuti aturan pondok pesantren meskipun banyak aturan yang tertulis. Banyak alumni yang berhasil, mereka dipercaya oleh masyarakat dalam memimpin kegiatan keagamaan, sehingga banyak menarik masyarakat untuk memasukan putra dan putrinya ke Pondok Pesantren AlHikamussalafiyah Purwakarta. Para alumni yang telah lulus masih menjalin silaturahmi dengan pihak pondok pesantren, karena ketakdiman mereka kepada kyai, sehingga tidak melupakan lembaga tempat ia belajar dulu. Para orang tua santri yang mempercayai kepada pihak pesantren menitipkan putra-putrinya untuk menuntut ilmu di Pondok Pesantren Al-Hikamussalafiyah Purwakarta.

Faktor penghambat dipengaruhi oleh lingkungan luar pesantren, khususnya pengurus yang terlibat dalam kegiatan tersebut, pengurus yang menempuh pendidikan formal di jenjang perguruan tinggi yang berada diluar komplek pesantren kadang berbenturan kegiatannya, sehingga menghambat pengurus dalam melaksanakan tugasnya, ketika pengurus yang masih ada kegiatan diluar pondok, mereka terkadang pulang sampai sore bahkan sampai larut malam, sesampainya di pesantren mereka kelelahan sehingga kurang maksimal dalam menjalankan tugasnya. 
Faktor manusia tidak dapat diabaikan begitu saja, faktor tersebut penentu keberhasilannya. Sebuah sistem yang berubah harus diikuti dengan perubahan pengetahuan, keterampilan dan sikap manusianya (Sutrisno, 2011, p. 89). Dalam mengelola sebuah lembaga khususnya lembaga pendidikan, tidak akan terlepas dari faktor pendukung dan faktor penghambat, dengan adanya faktor pendukung tersebut, maka sebuah lembaga perlu mempertahankan atau lebih meningkatkannya lagi agar menjadi lebih baik, sedangkan dengan adanya faktor penghambat maka perlu adanya sebuah evaluasi. Faktor penghambat terjadi karena adanya sebuah perubahan, didalam sebuah organisasi biasanya adalah manusia, karena organisasi merupakan kumpulan orang, maka dari itu perlu adanya sebuah perhatian, karena seseorang yang didengarkan pendapatnya cenderung akan lebih berpartisipasi terhadap organisasi atau lembaganya.

\section{SIMPULAN}

Pemimpin kharismatik memiliki ciri-ciri yang sangat menonjol yaitu memiliki visi yang jelas, dalam kepemimpinannya $\mathrm{KH}$. Adang Badruddin mempunyai visi yaitu Pondok Pesantren Al-Hikamussalafiyah Purwakarta sebagai lembaga pendidikan yang beraqidah Ahlussunnah Wal Jama'ah yang mampu membentuk pribadi santri menjadi insan kamil dan syamil, dan mampu mencetak intelektual muslim yang kompeten dengan bekal IMTAK dan IPTEK. Visi tersebut dituangkan dalam misi pesantren. $\mathrm{KH}$. Adang Badruddin juga merupakan pemimpin yang tegas dan disiplin yaitu ketika santrinya melakukan kesalahan, beliau dengan tegas memberikan sanksi pada santrinya.

Dalam pelaksanaan kepemimpinannya KH. Adang Badruddin mempunyai beberapa program yaitu program harian, program mingguan, program bulanan dan program tahunan. Program harian yang terdiri dari kegiatan belajar mengajar dan shalat berjamaah. Program mingguan dan bulanan terdiri dari kegiatan yang diikuti oleh seluruh santri dan masyarakat, pada program bulanan diadakan pertemuan orang tua santri dan pengajian bulanan. Program tahunan merupakan agenda pesantren yang rutin dilaksanakan setiap setahun sekali yang diikuti oleh seluruh santri dan masyarakat.

Hasil yang dicapai $\mathrm{KH}$. Adang Badruddin dalam kepemimpinannya yaitu jumlah santri yang selalu bertambah setiap tahunnya, ditahun ajaran 2018/2019 jumlah santri 5000 . telah berhasil mengembangkan lembaganya baik pendidikan formal maupun pendidikan non formal yaitu Raudhatul Athfal (RA), Madrasah Ibtidaiyah (MI), Sekolah menengah Pertama (SMP), Sekolah Menengah Atas (SMA), Sekolah Menengah Kejuruan (SMK), Kampus 2 Universitas Islam Nusantara (Uninus) yang masih menginduk ke Uninus Bandung. Sedangkan pendidikan non formalnya yaitu Madrasah Diniyah Takmiliyah Awaliyah (MDTA). Keberhasilan beliau ditandai juga dengan lulusan alumninya. Alumni yang lulus dan pulang ke rumahnya masing-masing, mereka dipercaya oleh masyarakat untuk memimpin setiap kegiatan keagaamaan.

Terdapat tiga faktor pendukung, yaitu santri, alumni dan orang tua santri. Sedangkan faktor penghambatnya yaitu dari luar lingkungan pondok pesantren, pengurus pondok pesantren yang menempuh pendidikan formalnya diluar pondok yang berbenturan kegiatannya, sehingga menghambat mereka dalam melaksanakan tugasnya dan tidak maksimal. 


\section{REFERENSI}

Ansor, A. S. (2014). Manajemen Pendidikan Islam Tentang Kepemimpinan Kiai Di Pondok Pesantren. EDUKASI ISLAMI: Jurnal Pendidikan Islam, 3(6), 650-662. https://doi.org/10.30868/ei.v3i06.54

Djasadi, D., Wasino, W., \& Sumaryanto, T. (2012). Faktor-Faktor Yang Mempengaruhi Keberhasilan Kyai Kharismatik Dalam Memimpin Pondok Pesantren. JERE: Journal of Educational Research and Evaluation, 1(2), 146-151. https://journal.unnes.ac.id/sju/index.php/jere/article/view/883

Engku, I., \& Zubaidah, S. (2014). Sejarah Pendidikan Islami. Remaja Rosda Karya.

Faris, A. (2015). Kepemimpinan Kiai Dalam Mengembangkan Pendidikan Pesantren. 'Anil Islam: Jurnal Kebudayaan Dan IImu Keislaman, 8(1), 123144. http://jurnal.instika.ac.id/index.php/Anillslam/article/view/39

Fauzi, I. (2016). Manajemen Pendidikan Ala Rasulullah. Ar-Ruzz Media.

Fithriah, N. (2018). Kepemimpinan Pendidikan Pesantren (Studi Kewibawaan Pada Pondok Pesantren Salafiyah, Modern, dan Kombinasi). Al Qalam: Jurnal IImiah Keagamaan Dan Kemasyarakatan, 12(1), 13-30. https://doi.org/10.35931/aq.v0i0.17

Hidayat, A., \& Machali, I. (2012). Pengelolaan Pendidikan: Konsep, Prinsip, dan Aplikasi dalam Mengelola Sekolah dan Madrasah. Kukaba.

Ibrahim, R. (2014). Eksistensi Pesantren Salaf di Tengah Arus Pendidikan Modern (Studi Multisitus pada Beberapa Pesantren Salaf di Jawa Tengah). Analisa: Journal of Social Science and Religion, 21(1), 253-263. https://doi.org/10.18784/analisa.v21i02.19

Komariah, N. (2016). Pondok Pesantren sebagai Role Model Pendidikan Berbasis Full Day School. HIKMAH: Jurnal Pendidikan Islam, 5(2), 183-198. https://ojs.staituankutambusai.ac.id/index.php/hikmah

Kusdiana, A. (2014). Sejarah Pesantren (Jejak, Penyebaran, dan Jaringannya di Wilayah Priangan 1800 - 1945). Humaniora.

Marginingsih, R. (2017). Kepemimpinan Karismatik Sebagai Employer Branding. Jurnal Bisnis Darmajaya, 2(2), 32-51. https://jurnal.darmajaya.ac.id/index.php/JurnalBisnis/article/view/706

Moleong, L. J. (2011). Metodologi Penelitian Kualitatif. Remaja Rosda Karya.

Soebahar, H. (2013). Modernisasi Pesantren: Studi Transformasi Kepemimpinan Kiai dan Sistem Pendidikan Pesantren. LKiS.

Sunardi, S. (2017). Kepemimpinan Kiai dalam Pengembangan Pondok Pesantren Al Urwatul Wutsqo Jombang (Studi Kasus di MTs Salafiyah Syafi'iyah Tebuireng). Al-Idaroh: Jurnal Studi Manajemen Pendidikan Islam, 1(1), 117-137. https://doi.org/10.54437/alidaroh.v111.10

Sutrisno, E. (2011). Budaya Organisasi. Kencana.

Zulhimma, Z. (2013). Dinamika Perkembangan Pondok Pesantren Di Indonesia. Darul 'Ilmi: Jurnal Ilmu Kependidikan Dan Keislaman, 1(2), 166-167. https://doi.org/10.24952/di.v1i02.242

Zunaih, A. I. (2017). Gaya Kepemimpinan Kyai Abdul Ghofur dalam Pengembangan Pondok Pesantren Sunan Drajat. Ummul Qura: Jurnal Institut Pesantren Sunan Drajat (INSUD) Lamongan, 10(2), 1-17. https://ejournal.insud.ac.id/index.php/UQ/article/view/52 